\title{
Sürdürülebilir Kırsal Kalkınma Uygulaması Örneği: Yukarı Avusturya, Ottenschlag Köyü ve Mooswiesen Biyolojik Göleti Peyzaj Planlama Projesi
}

\author{
Gül Aslı Aksu ${ }^{1 *}$ \\ 1* Kastamonu Üniversitesi, Mühendislik ve Mimarlık Fakültesi, Peyzaj Mimarlığı Bölümü, Kastamonu, Türkiye, (ORCID: 0000-0002-6847-6182), \\ gaaksu@kastamonu.edu.tr / aslibozbay@yahoo.de
}

(İlk Geliş Tarihi 29 Temmuz 2021 ve Kabul Tarihi 21 Kasım 2021)

(DOI: 10.31590/ejosat.976165)

ATIF/REFERENCE: Aksu, G.A. (2021). Sürdürülebilir Kırsal Kalkınma Uygulaması Örneği: Yukarı Avusturya, Ottenschlag Köyü ve Mooswiesen Biyolojik Göleti Peyzaj Planlama Projesi. Avrupa Bilim ve Teknoloji Dergisi, (27), 1061-1072.

$\ddot{O} \mathbf{z}$

Kültürel Peyzaj; insan müdahaleleri ile şekillenen, geçmişin aynası, geleceğin göstergesi niteliği taşıyan, günümüz kullanımlarına ve doğal-külttürel mirasa ev sahipliği yapan, çevrenin önemli bileşenidir. Ölçek itibariyle, ekosistem ile biyom arasında yer alan peyzajların kalitesi ve çeşitliliği ortak bir kaynak oluşturmaktadır. "Avrupa Peyzaj Sözleşmesi” ile bu kaynağın iş birliği ile korunmasına, yönetilmesine ve planlanmasına önem verilmektedir. Peyzajların envanteri ve sürdürülebilirlik ilkelerine göre değerlendirilip kullanımlara yönelik stratejiler geliştirilmesi, kullanıcıların yaşam kalitesinin ve halk sağlığının iyileştirilmesi ve biyolojik çeşitliliğin korunup teşvik edilmesi adına da önemli bir katma değer sağlamakta, ekonomik kalkınmayı desteklemektedir. Avrupa Birliği'nin Natura 2000 ağı ile başlattığı önemli türlerin ve yaşama ortamlarının korunup geliştirilmesine yönelik hamlesinin, "Avrupa Yeşil Mutabakatı" ile daha üst seviyelere taşınması hedeflenmektedir. Ekosistem bozulması önemli yıkımlara ve kayıplara sebep olmaktadır. Daha iyi bir gelecek ve doğal kaynakların sürdürülebilirliğini sağlamak için kültürel müdahalelerin ve kullanımların, biyoçeşitlilik ve ekosistemler üzerindeki etkilerinin tespit edilmesi ve değerlendirmesi gerekmektedir. Peyzaj fonksiyonları, bu açıdan gösterge niteliği taşımaktadır. İçerisinde çok sayıda fonksiyonun cereyan ettiği kültürel peyzajların planlanması ve restorasyonu, sürdürülebilir kalkınma adına önem kazanmakta ve her geçen gün daha elzem hale gelmektedir. Tüm bu özelliklerinden ötürü sürdürülebilir planlama ve doğala yakın peyzaj tasarımı konularına örnek olarak seçilmiş olan "Ottenschlag Köyü Sürdürülebilir Kalkınma ve Mooswiesen Biyolojik Göleti Projesi”nin uygulama süreci, bu makalede kapsamlı olarak değerlendirilmiş̧tir.

Anahtar Kelimeler: Kültürel Peyzaj, Uygulama Projesi, Sürdürülebilir Kalkınma, Peyzaj Fonksiyonu, Peyzaj Planlama.

\section{A Sustainable Rural Development Implementation: Upper Austria, Ottenschlag Village and Mooswiesen Ecological Lake Landscape Planning Project}

\begin{abstract}
Cultural Landscapes are important components of the environment shaped by human interventions. They are mirrors of the past and indicators of the future, while currently hosting highly diverse anthropogenic uses and the natural-cultural heritage. As a scale, the landscapes located between ecosystems and bioms are forming a common source with their quality and diversity. The "European Landscape Convention" cares about the protection, management and planning of this highly diverse resource. Sustainable developing strategies improve the quality of life and public health and promote biological diversity as well. They also support economic development. The EU goal to protect and develop important species and habitats is currently being moved to higher levels with ambitious goals of the "European Green Deal". Ecosystem degradation causes significant destruction and losses. To ensure a better future and sustainability of natural resources, it is necessary to identify and evaluate the impacts of cultural interventions and uses on biodiversity and ecosystems. Landscape functions are indicative in this respect. The planning and restoration of cultural landscapes, in which many functions take place, are gaining importance for sustainable development and are becoming more and more essential. The implementation process of the "Ottenschlag Village Sustainable Development and Mooswiesen Ecological Lake Landscape Planning Project", which has been chosen as an example for sustainable planning and natural landscape design due to all these features, has been comprehensively evaluated in this article.
\end{abstract}

Keywords: Cultural Landscape, Implementation Project, Sustainable Development, Landscape Function, Landscape Planning.

*Sorumlu Yazar: gaaksu@kastamonu edu tr / aslibozbay@yahoo.de 


\section{Giriş}

Günümüzde "Kültürel Peyzaj”, doğal ve insan eylemi sonucu ortaya çıkmış habitatlar arasında köprü görevi gören; peyzaj yönetimi ve planlamasında önemli bir adım taşı teşkil eden ve bu özellikleri dolayısıyla hassasiyetle ele alınması gereken bir kavramdır. Kültürel peyzajların bütüncül bir bakış açısıyla anlaşılması için barındırdıkları flora, fauna, cansız çevre ve kültürel çeşitlilik bakımından değerlendirilmeleri ve karakteristiklerinin ortaya konulması gerekmektedir. $\mathrm{Bu}$ karakteristikler sürdürülebilir planlama ve kalkınma açısından gerek biyolojik çeşitliğin korunması ve teşvik edilmesinde, gerek medeniyetler arası köprülerin kurulmasında ve gerekse sürdürülebilir kalkınmanın teşvik edilmesinde önemli kimlik değerleri ve göstergeler barındırmaktadır.

1992 yılında "Kültürel Peyzaj” kategorisi Dünya Mirası Komitesi tarafından kabul edilerek, "Dünya Kültürel ve Doğal Mirasın Korunması Sözleşmesi” (1972 yılında UNESCO tarafından kabul edilen ve ülke olarak 1982 y1lında taraf olduğumuz) kapsamına alınmış ve böylelikle kültürel peyzajların korunmasına yönelik öncül bir çerçeve teşkil etmiştir (Ürün, 2016; URL-1).

Avrupa Konseyi 1995 tarihli ve "Peyzaj Politikalarının Bir Parçası Olarak Kültürel Peyzaj Alanlarının Bütünleşmiş Korunması" başlıklı tavsiye kararında ise sanayi, turizm, konut yerleşimleri, tarım, ormancılık vb. unsurlara yönelik gelişme ve dönüşümlerin kültürel peyzaj alanlarında oluşturduğu tehlikelere dikkat çekilerek, bu alanların kültürel, ekolojik, ekonomik, sosyal boyutlar içeren, yerel-ulusal mekanizmaları koordine eden çok boyutlu sistemlerle korunmasını önermiştir (Avrupa Komisyonu, 1995; Kayın, 2012). Böylelikle 90’lı yıllarda kültürel peyzajların korunmasına yönelik önemli düzenlemelerin ilk adımları atılmıştır.

2000 yılında Floransa'da yürürlük kazanan ve ülkemizin de 2003 y1lında taraf olduğu "Avrupa Peyzaj Sözleşmesi'ne (APS)" göre; kültürel ve doğal mirasın en önemli parçası olarak Peyzaj, yerel kültürlerin oluşumuna ve kimlik değerlerinin sağlamlaştırılmasına önemli katkılar sağlamaktadır. Peyzajın; her yerdeki insan için, kırsal ve kentsel; yüksek kaliteli ve bozulmuş, sıradan ve sıra dışı güzelliklere sahip olan alanlarda yaşam kalitesinin oluşturulması ve muhafaza edilmesinde önemli rolleri vardır. Peyzajların kalitesi ve çeşitliliği ortak bir kaynak oluşturmaktadır ve bunun korunmasında, yönetilmesinde ve planlanmasında iş birliği önem kazanmaktadır. Yine APS'ye göre "Peyzaj Koruma" Peyzajların önemli ve karakteristik özelliklerinin korunması ve devamı için yapılan işlemlerdir ve bunlar da peyzajın doğal biçimi ve/veya insan faaliyetlerinden kaynaklanan miras değeri ile kararlaştırılmaktadır.

APS (2003), Madde 5 a.'ya göre; “Peyzajları, yasa çerçevesinde, insanların çevrelerinde gerekli olan bir unsur olarak tanımak ve ortak olarak paylaşılan kültürel ve doğal mirasın çeşitliliğinin bir ifadesi ve insanların kimliklerinin bir esası olarak kabul etmek;" gerekmektedir. Bu anlamda peyzajın korunması, yönetilmesi ve planlanması amacıyla peyzaj politikalarının oluşturulması ve uygulanması, ülkenin refahı ve sosyal yaşam konforu açısından büyük önem taşımaktadır. Bu kapsamda değerlendirildiğinde, biyolojik çeşitliliğin korunmas1 ve teşvik edilmesi, ekosistem hizmetlerinin sağlıklı bir çerçevede sürdürülebilmesi, halk sağlığının korunması gibi hayati konular açısından önem taşıyan Peyzaj planlama ve yönetiminin ulusal ve uluslararası düzeyde önemli bir sorumluluk haline geldiği anlaşılmaktadır.

\section{Kapsam}

Kültürel peyzajlar doğal habitatlarla kültürel faaliyetler arasında önemli bir arakesit teşkil ettikleri için öncelikle bu bağlamda genel çerçeve teşkil edecek konular üzerinde durulmuştur.

\subsection{Kültürel Peyzaj ve Biyolojik Çeşitlilik}

Kültürel peyzajlar, insan ve doğanın bütünlüğü ve kültürel mirasın önemli bir parçasıdır (Tülek ve Saner, 2020). Kültürel Peyzajlar, doğal özellikleri insan faaliyetleri tarafindan değiştirilmiş olan ve peyzaj içerisinde katmanlar halinde izler bırakan desenler şeklinde kendini gösteren alanlardır. $\mathrm{Bu}$ katmanlar, doğal özelliklerle birlikte bir peyzaja tanımlayıcı, tarihi, estetik, sembolik ve akılda kalıcı karakterini kazandırırlar. Kültürel peyzajların tanımlanması, sahip oldukları değerleri korumak üzere gerekli politikaların geliştirilmesi ve zamanla meydana gelen mekânsal ve sosyal değişimin yönetilebilmesi ve sürdürülebilir kullanımlara olanak tanınabilmesi gerekmektedir (Lennon, 2015).

ICOMOS, Floransa Bildirgesi (2014) ile bir yandan kültürel peyzajların koruması gereken alanlar olarak algılanması gerektiğini vurgularken, diğer yandan sürdürülebilir gelişme stratejilerinin başarıyla uygulanabileceği yerler olma potansiyelini de özellikle ön plana çıkartmaktadır.

Doğal-kültürel bileşenler ve bunlar arasındaki işleyişler, kültürel peyzajların zaman-mekân boyutunda bütüncül arakesitler sunmasını sağlamakta ve bu yapı, sürdürülebilir kalkınma girişimleri için çok elverişli bir temel teşkil etmektedir.

Kültürel Peyzajların planlanmasında üzerinde durulması gereken iki önemli hedef bulunmaktadır (Hampicke, 2013)

1- Biyolojik çeşitliliğin korunması ve teşvik edilmesi,

2- İnsanların yaşam kalitesini ve konforunu arttırarak sürdürülebilir kalkınmayı desteklemek.

Her iki hedefe de benzer yaklaşımlar ve stratejilerle ulaşılması mümkün olabilmektedir. Temel olarak geleneksel kültür peyzajlarını tehdit eden ve yıkıma neden olan kullanımların engellenmesi ve sürdürülebilirlik kapsamında yönetilmesi önem kazanmaktadır.

Biyolojik çeşitlilik, türler (flora-fauna) ve yaşama ortamları üzerinde etkili olan doğal-kültürel faktörlerle ilgili bir kavramdır ve sağlıklı yönetilebilmesi için bu çerçevede ele alınması gerekmektedir. Kültürel Peyzajlar, özellikle korunmaya değer, birbirleriyle potansiyel olarak yakın işlevsel bağlantı içinde olan ve dolayısıyla ekolojik ilişkileri temsil eden benzer, mekânsal olarak komşu habitatların sistemleridir.

Kültürel Peyzajlar, göstergesi oldukları bu doğal-kültürel bileşenler dolayısıyla doğa koruma ve peyzaj bakımı çalışmalarının odağında yer almaktadır. Bir yandan biyolojik çeşitliliğin şekillendiği mekanlar olarak barındırdığı değerlerle 
birlikte ekosistem fonksiyonlarını yerine getirirken, diğer yandan somut olan ve somut olmayan kültürel mirasa ev sahipliği yapan ve insanların rekreasyon, estetik ve konfor ihtiyaçlarına da cevap veren mekanlar olarak algilanmaktadır. Koruma-kullanma ilişkilerinin arakesitinde yer almaları nedeniyle sınıflandırılmaları, korunmaları ve geliştirilmeleri büyük önem taşımaktadır. Almanya'da Kültürel Peyzajlar, bu özellikleri ile "Doğa Koruma Yasası" kapsamında tanımlanmakta ve önemli fonksiyonlar üstlenmektedir (Heiland vd., 2017).

Enerji potansiyelleri ve bunların kullanımına yönelik tercihler de kültürel peyzajların şekillenmesi üzerinde önemli bir etkiye sahiptir (Demuth ve ark., 2014). Bu potansiyeller, aynı zamanda teknik altyapı ve enerji sistemlerinin peyzajın içerisine entegre edilebilmesi ve planlanması açısından da önem taşımaktadır (Hartz ve Brenner, 2017). Biyolojik çeşitliliğin korunması ve iyileştirilmesi bu potansiyeller konusunda sürdürülebilir kararlar alınıp alınamamasıyla doğrudan ilişkilidir. O nedenle potansiyelleri anlamak, kullanımlar ve doğal bileşenlerle ilişkilendirmek, sürdürülebilir peyzaj planlamasının önceliklerinden olmalıdır.

\subsection{Peyzaj Ekolojisi ve Sürdürüllebilirlik}

Naveh (2001)'in bir dizi işlevi barındıran "Gestalt Sistemi" olarak tanımladığı peyzajların karmaşık yapısının bütüncül bir yaklaşımla anlaşılması ve bileşenler arasındaki önemli etkileşimlerin ortaya konulması, peyzajların doğru bir şekilde planlanıp yönetilmesinde önem taşımaktadır. Özellikle hızlı bir dönüşüm süreci içerisinde olan peyzajlarda habitatların hızla yok olması ve biyolojik çeşitliliğin azalması gibi tehditlerin önüne geçilmek isteniyorsa, peyzaj plancılarına önemli roller düşmektedir. $\mathrm{Bu}$ sürecin sağlıklı bir şekilde yönetilmesi ise çevrenin sosyal ve kültürel bileşenlerle birlikte ele alınmasını gerektirmektedir. Bunun için doğa yasalarının, ekonomik süreçlerin ve sosyal karakteristiklerin ve bunlar arasındaki kompleks etkileşimlerin bir bütün olarak ele alınması; doğatoplum etkileşimlerini belirleyecek kavramsal modellerin ve araçların geliştirilmesi gerekmektedir (Darmstad vd., 1996; Miller vd.; 1998; Steinhardt vd., 2005; Potschin ve HainesYoung, 2006; McHarg, 1992; Bailey, 2002; Suri, 2018; Kayacan vd., 2019).

Günümüzde "Sürdürülebilirlik Bilimi” sosyal, çevresel ve ekonomik konular arasındaki kompleks, dinamik etkileşimleri anlamaya çalışır (Kasemir vd., 2003). Sürdürülebilirlik; doğal veya kültürel, geleneksel veya çağdaş, gösterişli veya sıradan peyzajlarla ilgili olabilir. Bu konsept, köylerde veya kırsal peyzajlarda geleneksel tekniklerin sürdürülmesi şeklindeki çalışmalarda uygulanabileceği gibi, doğal peyzaj kalıntılarının veya yoğun kullanılan peyzajların arazi kalitesinin geliştirilmesiyle de ilgili olabilir, bu nedenle sürdürülebilirliğin peyzaj planlaması için temel prensip olarak ele alınması gerekir (Antrop, 2006). Dolayısıyla sürdürülebilir kalkınmanın temel bileşenleri, bütüncül bir planlama anlayışıyla ele alınmalıdır (Aksu, 2017). Bunun için peyzaja ait sosyal desenlerin, kültürel desenlerle (insan grupları, onların etkileşimleri, onların mekânsal düzenlenişleri) birlikte sürece dahil edilmesi önem kazanmaktadır (Forman, 2008).

Ekosistemlerdeki bozulmaların eşik noktaları bulunmaktadır. $\mathrm{Bu}$ eşik aşıldığında, ekosistem kendini yenileyemeyecek hale gelmektedir. Ancak bu eşik aniden belirmez. Ekosistemler indikatörler (göstergeler) vesilesiyle çok sayıda sinyal de verir. Peyzaj planlamanın kilit görevi, mekanların planlama ve tasarım aşamaları sırasında eşik noktasına henüz ulaşılmamışken bu sinyalleri yakalamak ve eşikler aşılmadan bozulmayı tersine çevirebilecek müdahalelerde bulunmaktır (Aksu, 2020).

Peyzaj planlamasının, disiplinler arası platformlarda yerini alabilmesi için, koruma önceliklerini ortaya koyan, ancak kullanma ihtiyacını da göz ardı etmeyen bir bakış açısını yansitmas1 gerekmektedir. $\mathrm{Bu}$ anlamda Peyzaj Planlamas1, sosyal bilimlerle doğa bilimleri arasında köprü görevi gören yaklaşımlar sunabilmektedir. Özellikle Peyzaj Ekolojisi, peyzaj deseni ile peyzaj fonksiyonları arasındaki kompleks ilişkilerin bütüncül ve sürdürülebilir bir algıyla yönetilmesini sağlayan önemli bir çerçeve halini almıştır. $\mathrm{Bu}$ çerçevede, peyzaj desenleri metrikler yardımıyla değerlendirilebilmekte, peyzaj fonksiyonlarına odaklanan ekolojik göstergeler yardımıyla, ekolojik akışlar ve döngüler yorumlanabilmekte daha da önemlisi disiplinler arası katılımla doğal, sosyal ve kültürel bileşenler peyzaj planlama sürecine dahil edilebilmektedir.

\subsection{BM ve AB'nin Sürdürülebilir Kalkınma ve Habitat Koruma Yaklaşımları}

"Sürdürülebilir Kalkınma" kavramı, özellikle 80'li yılların başında "Ortak Geleceğimiz Çağrısının” (Brundtland Raporu), (UN, 1987) deklare edilmesiyle birlikte ivmelenerek hem Birleşmiş Milletlerin (BM) hem de Avrupa Birliği (AB)'nin ana gündem maddelerinden birisi haline gelmiştir. Sürdürülebilirliği sağlama gayesi, biyolojik çeşitliliğin korunması ve teşvik edilmesi hedefleriyle birlikte her geçen gün daha fazla önem kazanmaktadır.

1992 BM Rio Konferansı, özellikle "Çevre" ve "Kalkınma" konularına odaklanmış ve önemli çıktılar ortaya koymuştur. $\mathrm{Bu}$ çıktılardan olan Gündem 21 ve ona bağlı olarak şekillenen Yerel Gündem 21 hamlesi, bir eylem planı niteliği taşımaktadır ve bu anlamda önemli bir teşvik teşkil etmiştir. "Orman İlkeleri", "İklim Değişikliği Çerçeve Sözleşmesi”" (ve kapsamında imzalanan Kyoto Protokolü) ile "Biyolojik Çeşitlilik Sözleşmesi” gibi önemli metinlerin imzaya açılmış olması, konferansın küresel ölçekteki diğer hayati çıktıları olmuştur. 1994 yılında imzaya açılan "BM Çölleşme ile Mücadele Sözleşmesi” de yine Rio Konferansı'nda alınan kararlara göre şekillendirilmiştir.

2000'li yılların başlangıcına gelindiğinde, BM Binyıl Zirvesi (2000)'nde sürdürülebilir kalkınma adına küresel ölçekte önemli hedefler belirlenmiştir (Binyıl Kalkınma Hedefleri). Bu hedeflere göre sürdürülebilir çevre sağlama adına, sürdürülebilir kalkınma ilkelerinin ulusal mevzuatlarla uyumlu hale getirilmesi ve doğal-kültürel kaynakların korunması, biyo-çeşitliliğin geliştirilmesi, içme suyuna erişimin iki katına çıkarılması konuları değerlendirilmiștir. Rio Konferansı sonuçlarını değerlendirilmek ve Binyıl Kalkınma Hedeflerine uyarlamak üzere 2002'de, Johannesburg Dünya Sürdürülebilir Kalkınma Zirvesi düzenlenmiştir. 2012 yılında, Birinci Rio konferansından 20 yıl sonra yine Rio de Janerio'da Birleşmiş Milletler Sürdürülebilir Kalkınma Konferansı $($ Rio+20) düzenlenmiş ve konferansın çıktısı olarak "İstediğimiz Gelecek" adında, sürdürülebilir kalkınmaya kılavuzluk edecek sonuç belgesi kabul 
edilmiştir. 2015 yılında ABD-New York’ta, Binyıl Kalkınma Hedefleri'ni tamamlayacak şekilde, "BM Sürdürülebilir Kalkınma Hedefleri (Gündem 2030)" kabul edilmiştir. Bu hedefler sayesinde sürdürülebilir şehirler, iklim değişikliği, kuraklıkla mücadele, biyolojik çeşitliliğin korunması gibi çevre konuları sürdürülebilir kalkınma gündemine alınmıştır. Özellikle Sürdürülebilir Kalkınma Hedeflerinde yer alan 11, 13, 14 ve 15 numaralı hedefler kültürel peyzajlarla doğrudan ilintilidir:

Hedef 11: Şehirlerin kapsayıcı, güvenli ve sürdürülebilir yapılandırılmasını;

Hedef 13: İklim değişikliği ve etkileriyle mücadele için acilen eyleme geçilmesini;

Hedef 14: Okyanuslar, denizler ve su kaynaklarının korunması ve sürdürülebilir kullanımını;

Hedef 15: Kara ekosistemlerinin korunmasını, iyileştirilmesini ve sürdürülebilir kullanımının teşvik edilmesini, sürdürülebilir orman yönetimini, çölleşmeyle mücadeleyi, arazi bozulumunun durdurulmasını ve geriye çevrilmesini, biyolojik çeşitlilik kaybının durdurulmasını öngörmektedir (T.C. Dışişleri Bakanlığ 1,2021$)$.

Avrupa Birliği de sürdürülebilir kalkınma, doğal-kültürel mirasın korunması, biyolojik çeşitliliğin korunması ve geliştirilmesi, enerji kaynaklarının verimli kullanılması, yenilenebilir enerji kaynaklarının geliştirilmesi ve teşvik edilmesi, küresel iklim değişikliğini tetikleyen etkenlere karşı önlem alınması, su kaynaklarının yönetimi ve verimli kullanımı konularında küresel bir algıyla önemli girişimlerde bulunmuştur. Başta Avrupa'nın biyolojik çeşitliliğini korumak ve geliştirmek üzere Avrupa Komisyonu tarafindan Natura 2000 habitat ve tür koruma ağı oluşturulmuştur (Sundseth ve Creed, 2008). Bu ăg, 1979 yılında kabul edilen Yabani Kuşlar Yönergesinin devamı niteliği taşıyan Habitat Yönergesini odağına almakta ve Avrupa topraklarının yaklaşık \%18'ini koruma altına almayı hedeflemiştir (COM, 2013). Natura 2000 Programı çerçevesinde Avrupa Birliği'ne üye ülkeler, kendi sınırları içindeki en önemli doğal yaşam alanlarını ve buralardaki bitki ve hayvan türlerini tespit etmekle görevlendirilmiştir. Ülkelerden toplanan bu listeler, Avrupa Komisyonu'nun ilgili makamlarınca değerlendirilerek, koruma altına alınması gerektiği düşünülen bölgeler Natura 2000'in koruma ağı kapsamına alınmıştır.

\subsection{Avrupa Yeşil Mutabakatı (The European Green Deal)}

Günümüzde tüm bu çabaların devamı niteliği taşıyan "Avrupa Yeşil Mutabakatı”, 2050 yılına kadar AB'yi net sera gazı emisyonlarının olmadığı ve ekonomik büyümenin kaynak kullanımından ayrıştırıldığı modern, kaynak açısından verimli ve rekabetçi bir ekonomiye sahip, adil ve müreffeh bir topluma dönüştürmeyi amaçlayan yeni bir büyüme stratejisidir. AB doğal sermayesini koruyup geliştirirken, aynı zamanda vatandaşların sağlığını ve refahını çevre kaynaklı risk ve etkilerden korumayı da amaçlamaktadır. $\mathrm{Bu}$ geçişin adil ve kapsayıcı olması önemsenmektedir (Avrupa Yeşil Mutabakatı, 2021).



Şekil 1. Avrupa Yeşil Mutabakatı genel çerçevesi (Avrupa Komisyonu, The European Green Deal 2021)

Birincil hedefi 2050 y1lına kadar Avrupa iklimini ve emisyon oranlarını düzenlemek olan Avrupa Yeşil Mutabakatı (Avrupa Komisyonu, The European Green Deal 2021), aynı zamanda "Ekosistemlerin ve Biyolojik Çeşitliliğin Korunmasını ve İyileştirilmesini”, bununla birlikte, "Sürdürülebilir ve Akıllı Hareketliliğe Geçişin Hızlandırılmasını” da ana gündem maddesi olarak belirlemiştir (Şekil 1).

Avrupa Komisyonunun 2020 yılına kadar biyololojik çeşitliliğin korunmasına yönelik belirlediği stratejinin temel amacı "Biyolojik çeşitlilikte yaşanan kayıpların ve ekosistem hizmetlerindeki gerilemelerin engellenmesi" olmuştur. Bu çerçevede gerileme gösteren ekosistemlerin 2020 y1lına kadar asgari olarak \%15 oranında iyileştirilmesi hedeflenmiştir (COM, 2011). Bu nedenle 2020 yılına kadar Natura 2000 ağıyla belli bir seviyeye getirilen biyolojik çeşitlilik ve ekosistemlerdeki koruma ve iyileştirme çabaları, Yeşil Mutabakat ile bir üst seviyeye taşınarak daha da yüksek hedeflerle geliştirilmesi planlanmıştır (Avrupa Komisyonu, The European Green Deal 2021).

Yeşil Mutabakat, Avrupa Birliğinin 2020 yılına kadar tüm Avrupa arazi örtüsü/arazi kullanımlarının \%18'ini Natura 2000 ağı kapsamına alma hedefini; 2030 yılına kadar \%30 oranına çekmeyi amaç edinmiştir. Bu hedefe ulaşmanın temelinde doğalkültürel göstergelerden hareketle kültürel peyzajların, sahip oldukları kültürel değerler ve biyolojik çeşitlilik bakımından korunması, geliştirilmesi ve iyileştirilmesi yatmaktadır.

"Kültürel Peyzajlar"; çok sayıda ekosistem, habitat ve tür barındırma; kültürel faaliyetlerin zaman içerisindeki etkilerini ve sonuçlarını yansıtma ve doğal-kültürel ilişkilerin tanımlanmasını sağlayan önemli göstergelere sahip olma özellikleriyle, peyzaj planlama çalışmalarının odağında yer almalıdır.

\subsection{Ekosistem Fonksiyonlart}

Ekosistem fonksiyonları Kültürel Peyzajların sinıflandırılmasında önemli bir rol üstlenmektedir. Ekosistem bozulması önemli yıkımlara ve kayıplara sebep olmaktadır. Daha iyi bir gelecek ve doğal kaynakların sürdürülebilirliğini sağlamak için kültürel müdahalelerin ve kullanımların, biyoçeşitlilik ve ekosistemler üzerindeki etkilerinin tespit edilmesi ve değerlendirmesi gerekmektedir. Peyzaj fonksiyonları, bu açıdan gösterge niteliği taşımaktadır. Başta bitki, hava, su ve toprak ilişkileri olmak üzere, peyzaj içerisinde 
cereyan eden çok sayıda süreç, işleyiş ve etkileşim, peyzaja dair karakteristik değerleri teşkil etmektedir.

Ekosistemlerin sunduğu çeşitli fonksiyonlar, sosyal ve ekonomik sistemlerle ilişkilendirildiğinde, fayda ve değer arasındaki ilişkilere bağlı olarak değişimi tetiklediği görülmektedir. Dolayısıyla sahip olduğu ekosistem fonksiyonları, Kültürel Peyzajların şekillenmesinde de etkili olmaktadır (Avrupa Çevre Ajansı, 2021). Bu karşılıklı etkileşimlerin değerlendirilmesi koruma-kullanma dengeleri ve özellikle sürdürülebilir kalkınma hedefleri açısından önem taşımaktadır.

Ekosistem fonksiyonlarının sınıflandırılmasında çok sayıda yaklaşım bulunmaktadır (Heiland vd., 2017). En yaygın kullanılanlar, Milenyum Ekosistem Değerlendirmesi (Millenium Ecosystem Assessment - MA, 2005), Uluslararası Biyolojik çeşitlilik ve Ekosistem Ekonomisi Araştırması (The Economics of Biodiversity and Ecosystems - TEEB, 2010), Müşterek Uluslararası Ekosistem Hizmetleri Sinıflandırması (The Common International Classification of Ecosystem Services CICES, Haines-Young ve Potschin, 2013) ve Almanya için Bastian vd. (2013) tarafından tanımlanmış olan sınıflandırma sistemidir. Farklı peyzaj tiplerine göre değişebilmekle birlikte, özünde ekosistemlerdeki madde ve enerji hareketini şekillendiren süreçler olarak tanımlanan ekosistem fonksiyonları; (1) hidrolojik akış ve depolama, (2) biyolojik üretkenlik, (3) biyokimyasal döngü ve depolama, (4) ayrışma ve (5) biyolojik çeşitliliğin korunması konularını kapsamaktadır (Christensen ve Franklin, 1997). Bu noktada dikkati çeken husus, insanoğlunun doğrudan veya dolaylı olarak doğadan sağladığı yararların ekonomik değer olarak belirlenmesine dayanan ekosistem hizmetlerinin, ekosistem fonksiyonları doğru tanımlanmadığı sürece sosyo-ekolojik sistemlerdeki karmaşık etkileşimi basite indirgeme riski taşıdığıdır (Birkhofer vd., 2015). Dolayısıyla ekosistem fonksiyonlarının belirlenmesinin, ekosistem hizmetleri konseptini sıkça eleştirildiği gibi indirgemeci bir yaklaşım olmanın ötesine taşıyarak ve doğal süreçlerin karmaşıklığı ile bunların sosyo-kültürel süreçlerle etkileşimini anlamada anahtar role sahip olduğu konusuna vurgu yapılmaktadır (Saunders ve Luck, 2016).

Ekosistem hizmetlerinin peyzaj planlama ile olan ilişkisi konusunda Schrapp vd. (2020)'nın gerçekleştirdiği kapsamlı çalışmaya göre, ekosistem hizmetlerinin özellikle belediye ve bölge düzeyinde peyzaj planlamaya entegre edilmesi gerekmektedir. Bu katkının özellikle ekosistem fonksiyonlarının belirlenmesi ve ekosistem için kritik olan ilişkilerin ortaya konması yönünde olması önem taşımaktadır.

Dicks (2008), 2010 yılı dünya nüfusunu referans alarak, dünya kaynaklarının kullanım göstergesi olan ve kullanılan bütün yiyecekleri, yakıtları ve malzemeleri yetiştirmek için ihtiyaç duyulan arazinin miktarı olarak tanımlanan "Ekolojik Ayak İzi” için kişi başı 1,8 ha sürdürülebilirlik sınırı belirlemiştir. Aynı dönemde kişi başı 2,2 ha olarak tespit edilen dünya ortalaması, sürdürülebilirlik sınırının üstünde çıkmıştır. Dünya nüfusunun her geçen gün arttığı göz önünde bulundurulduğunda arazi kullanım baskısının, dolayısıyla ekolojik ayak izinin de artması kaçınılmaz görünmektedir. Önemli olan günümüz eko-ekonomi imkanları doğrultusunda hesaplama olanağı bulunan koruma-kullanma dengelerinin gözetilerek planlama ve tasarım kararlarına yansıyacak tedbirlerin alınmasidır.

Gerek ekosistem hizmetlerinin gerekse ekosistem fonksiyonlarının tespiti ve değerlendirilmesi çabalarının odağında ekosistem sağlığı yer almalıdır. Ekosistem sağlığının sürdürülebilirliği ise ancak sistemli bir planlama süreciyle sağlanabilmektedir. Öncelikle ekosistemlerin bileşenleri, işleyişleri ve diğer ekosistemlerle etkileşimleri ve bu etkileşimlerde meydana gelen problemler tespit edilmelidir. Biyolojide hiyerarşi düzeni basamaklarına göre ekosistemleri kapsayan bir kademe olarak "Peyzaj”, ekosistem sağlığını algılama, değerlendirme ve planlama açısından son derece kapsayıcı ve uygun bir ölçek teşkil etmektedir. Özellikle kültürel peyzajların, sundukları ekosistem fonksiyonları bakımından da değerlendirilmesi, yerel, bölgesel ve hatta ulusal ölçekte sürdürülebilir kalkınma stratejilerinin geliştirilmesine, dolayısıyla ekosistem sağlığına önemli katkılar sağlamaktadır.

Ancak bu yaklaşımlarda ihmal edilmemesi gereken başlica unsur, özellikle kültürel etkenlerle şekillenen "Kültürel Peyzajlar" söz konusu olduğunda, başlıca tetikleyici ve kullanıcı konumundaki insanın kendisidir.

Yukarıda anlatılan özelliklerinden yola çıkılarak Kültürel Peyzajların planlanması ve restorasyonu konularında örnek olarak seçilmiş olan “Ottenschlag Köyü Sürdürülebilir Kalkınma ve Mooswiesen Biyolojik Göleti Projesi”nin uygulama süreci, kapsamlı olarak değerlendirilmiştir.

\section{Materyal ve Metot}

Konuyla ilgili gerçekleştirilen çok sayıda ar-ge çalışması olmasına rağmen, sürdürülebilir kalkınmaya bütüncül bir yapıda katkı sağlayacak örnek uygulama projeleri, literatürde çok fazla yer bulamamaktadır. Oysaki çok bileşenli olan sürdürülebilir kalkınma kavramının, uygulama sürecine dönüştürülmesi önemli göstergeler içermektedir. $\mathrm{Bu}$ nedenle literatürde daha fazla örneğin yer alması; benzer uygulama projeleri ve konuyla ilgili ar-ge çalışmalarına örnek teşkil etmektedir. $\mathrm{Bu}$ zorlu sürecin başarıyla yönetildiği "Ottenschlag Köyü Sürdürülebilir Kalkınma ve Mooswiesen Biyolojik Göleti Projesi”nin planlama ve uygulama süreci bu makaleye konu edilmiştir.

\subsection{Projenin Kapsamı ve Genel Özellikler}

Avusturya Mühlkreis'taki Ottenschlag Belediyesi ile Sterngartl-Gusental Turizm Bölge Müdürlüğü işbirliğinde, planlaması ve uygulaması TBK-Kutzenberger tarafından gerçekleştirilen Mooswiesen biyolojik göleti, 2,5 ha su yüzeyine, geniş bataklık zonlarına ve 350 mtül dere yatağı restorasyon sahasına sahiptir (Şekil 2). Toplam proje sahası 5 ha büyüklüktedir. 

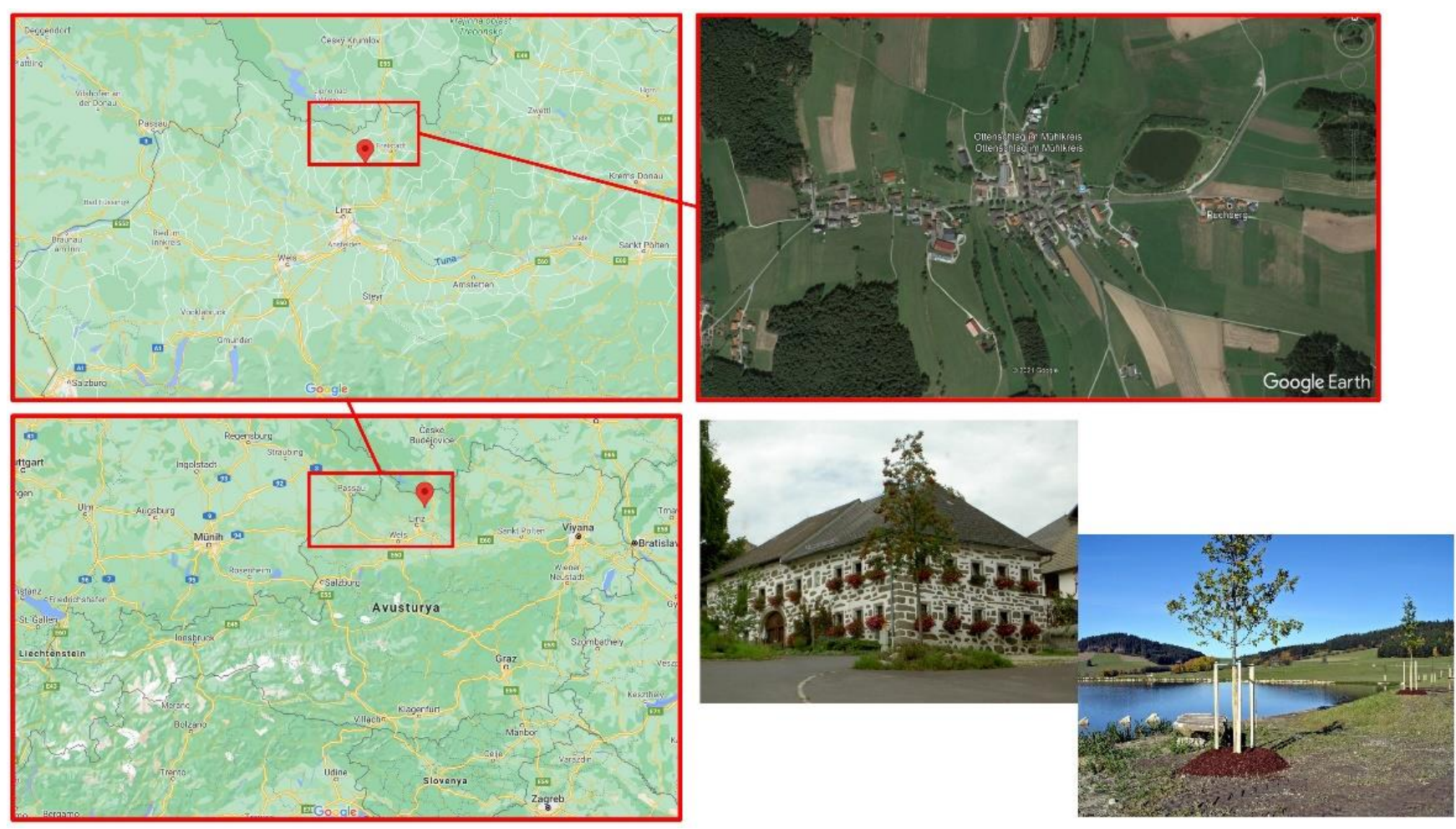

Şekil 2. Mooswiesen Biyolojik Göleti, Yukarı Avusturya’daki Mühlkreis Ottenschlag Köyü kalkınma projesinin önemli bir bileşeni olarak bir yandan rekreatif faaliyetlere olanak tanırken, diğer yandan yörenin su yönetimine ve biyolojik çeşitliliğine katkı sağlamaktadır.

Doğala yakın düzenleme prensiplerine göre tesis edilen uygulama alanı, bir yandan rekreasyonel ihtiyaçlara cevap verirken, diğer yandan biyolojik çeşitliliği arttıracak nitelikte tasarlanmıştır. Gölet sahasına altı adet kaya bahçesi, yöresel ve tarihi meyve ağaçlarından oluşan bir ağaç allesi ve dinlenme alanları eşlik etmektedir.

\subsection{Sürdürülebilir Köy Kalkınması}

Ottenschlag Köyü Projesi, sürdürülebilir kalkınmaya yönelik temel prensiplerden olan halk ve paydaş katılımını benimsemiş ve uygulama sürecine dahil etmiş olan bir projedir. Öyle ki tüm karar verme süreçlerinde yerel yönetimlerle birlikte halk katılım toplantıları düzenlenmiş ve paydaşlardan görüş alınmıştır. Bu yönüyle sürdürülebilir köy kalkınmasına örnek teşkil edebilecek niteliktedir. Aynı zamanda çok yönlü bir çevre projesi olan proje; doğa koruma, turizm, rekreasyon ve su yönetimi fonksiyonlarını entegre etmektedir.

Biyolojik gölet tercihi hem doğal koşulların uygunluğu (göleti besleyecek derenin varlığı, su baskınlarına karşı tedbir alınma gerekliliği, topoğrafyanın ve arazi örtüsünün uygunluğu vb.) hem de köy kalkınması için gerekli olan ekonomik itiş gücü göz önünde bulundurularak yapılmıştır. Bu kapsamda köydeki yapısal yüzeylerin (sert zeminler, köprü benzeri donatılar vs.) bakımı ve onarımı, ayrıca yapısal malzemede bütünlük ve uyumu sağlamak üzere, yörede yatakları bakımından zengin olan granit taş kullanılarak gerçekleştirilmiştir. Yöre halkı tarafından yapıların inşasında da granit taş malzemenin tercih edilmiş olması, malzemenin bütünlüğü sağlamak üzere kullanılmasını desteklemiştir. Köy yerleşim alanı içerisinde, ekonomik girdi sağlayabilmek ve ziyaretçi çekebilmek üzere yapılardan birinin hem eski çiftlik araç gereçlerinin sergilendiği bir müze hem de restoran olacak şekilde tahsis edilmiş olması, ziyaretçi potansiyelini arttırmışıır. Gerek Yukarı Avusturya'nın kendi şehirleri arasında, gerekse Linz ile Viyana şehirleri arasında merkezi bir konumda yer alan köy, gelir geçerler için bir uğrak noktası olabilecek durumdadır (Şekil 3,4).
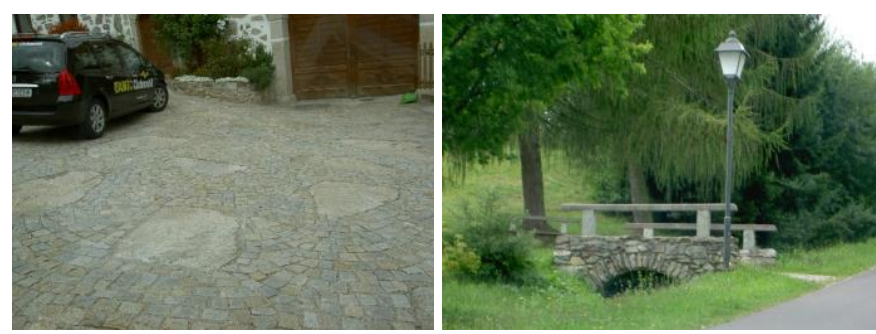

Şekil 3. Ottenschlag Köyü, granit yatakları zengin olan bir bölgede yer aldığı için köy evlerinin de baskın malzemesi olan granit taş, çevre düzenlemesinde de temel yapısal malzeme olarak tercih edilmiştir.

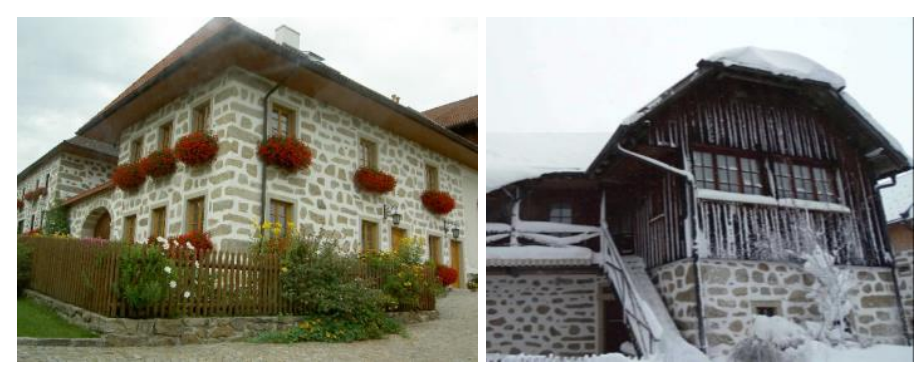

Şekil 4. Gelir geçerlere restoran hizmeti vermek suretiyle köyün ziyaretçi potansiyelini arttıran yapılar. 
Proje, bölgeye özgü doğal, kültürel karakteristik peyzaj bileşenlerinin çeşitliliğinin arttırılmasına da odaklanmaktadır. Çeşitlilik sergileyen ve farklı strüktürlerde tasarlanan habitatlar, insan faaliyetleri neticesinde zarar gören ve yaşam alanları daralan hayvan ve bitki türlerini teşvik etmektedir (Şekil 5).
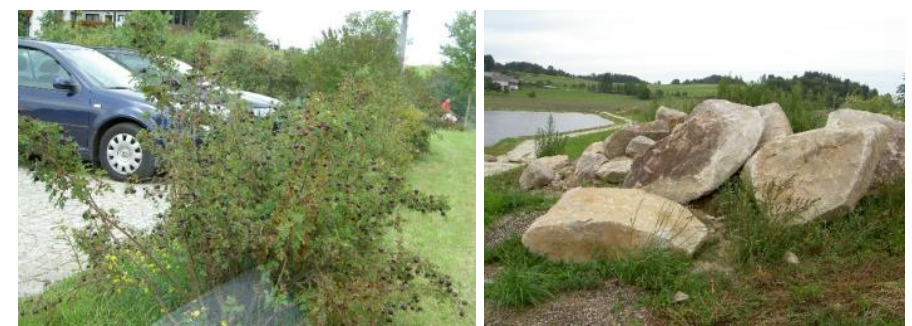

Şekil 5. Fauna çeşitliliğini arttırmak üzere yemiş veren sık dallı çalılar, köyün çevre düzenlemesinde tercih edilmiştir. Özellikle kertenkele gibi sürüngenler ve küçük memeliler için barınak teşkil etmesi için daha iri blok taşlardan inşa edilen tepecikler, manzara noktalarına yerleştirilerek eş zamanlı olarak rekreasyona da hizmet etmektedir.

Tasarlanan mekanlar, hem Mühlkreis Peyzajının karakteristiklerini ön plana çıkartarak ziyaretçilere tanıtmakta hem de rekreasyon ve doğa deneyimi için firsatlar sunmaktadır. Doğa gözlemi, yaban meyve ve yemişlerin dalından koparılması gibi faaliyetler bu deneyimlerden sayllabilir. Bununla birlikte onlarca yıldır kanala alınmış halde atıl durumda kalan Grasbach Deresi, yapılan düzenleme ve restorasyon sayesinde hem ekolojik hem de estetik açıdan değer kazanmıştır (Şekil 6).
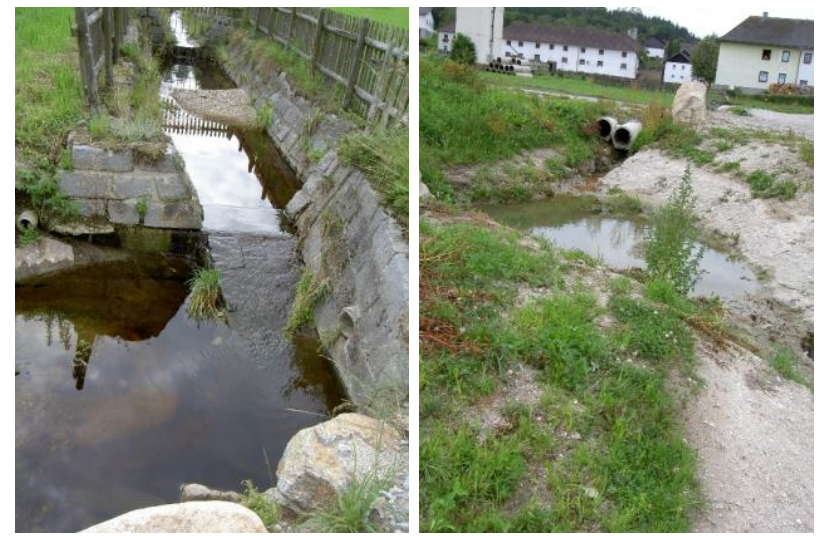

Şekil 6. Köyle ilişkilendirilmeden kanal ve borularla drene edilen Grasbach Deresi, proje sayesinde biyolojik göleti besleyen bir su sistemi olarak restore edilmiştir.

\subsection{Mooswiesen Biyolojik Göleti Tasarım ve Uygulama Süreci}

Öncelikle biyolojik gölet için tercih edilen arazinin gerek topoğrafya gerek geçirimlilik gerekse toprak tipi ve strüktürü bakımından gölet oluşturmak üzere son derece uygun olduğu tespit edilmiştir. Toprak, geçirimliliği düşük ve killi karakterdedir. Bu sayede gölet daha düşük maliyetlerle tesis edilebilmiştir. Öyle ki göletin tesisi için ilave izolasyon malzemesine ihtiyaç duyulmamıştır (Şekil 7). Başta yağış miktarı, Grasbach Deresinin debisi, toprak özellikleri ve infiltrasyon kapasitesi gibi parametreler; ortalama ve ekstrem değerler üzerinden değerlendirilerek göletin hacmi ve alanına karar verilmiştir. Bu kapasite hesaplamaları neticesinde göletin, 2,5 ha'lık bir su yüzeyine sahip olması kararlaştırılmıştır.

e-ISSN: 2148-2683

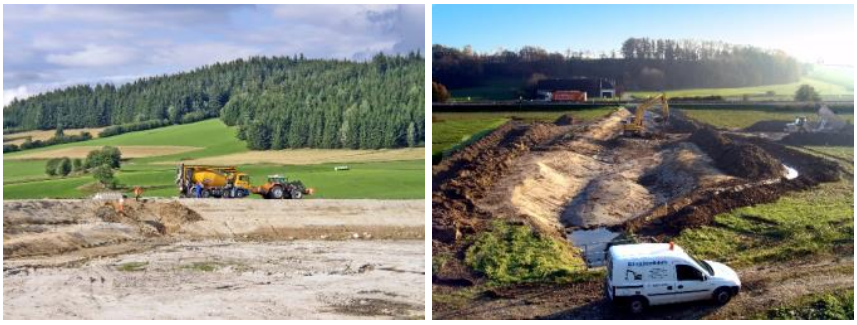

Şekil 7. Yapılan kapasite hesaplarından sonra biyolojik göletin kazı ve tesviye işlemlerine başlanmıştır.

Habitat ve tür çeşitliliğini teşvik etmek üzere yöredeki doğal sulak alanlardan temin edilen bitki kökleri kıyılara dikilmiştir. Sudaki oksijen miktarını arttırmak üzere, özellikle oksijen bağlama kapasitesi yüksek olan türler ayrıca temin edilerek bitkilendirme tasarımına dahil edilmiştir (Şekil 8,9).


Şekil 8. Gölet tesis edildikten sonraki yılda göl kenarında gelişen su kenarı habitatı.
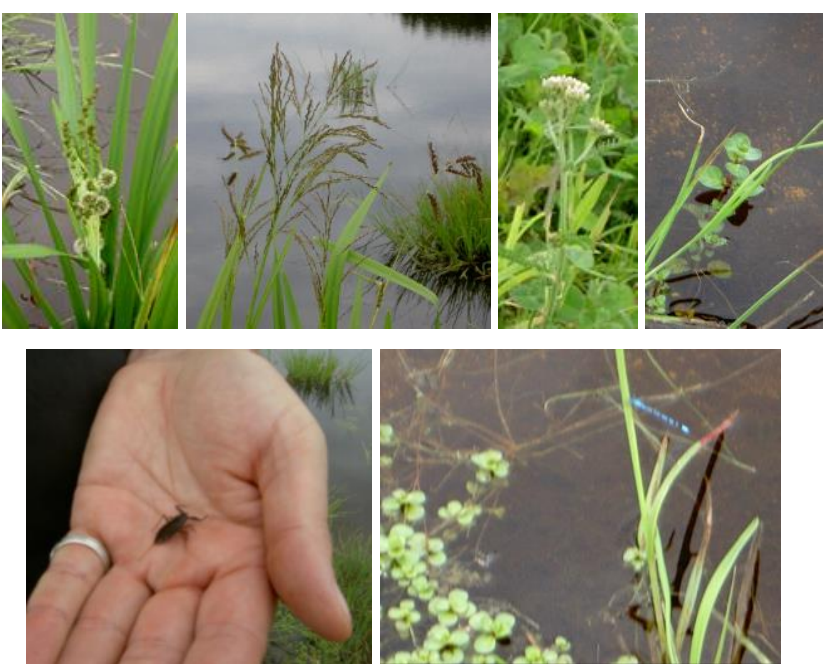

Şekil 9. Göl kenarında ve suyun içinde tercih edilen bitki türlerinde özellikle suyu temizleme, habitat teşkil etme ve yörenin vejetasyonuna uyum kriterleri göz önünde bulundurulmuştur (Sparganium sp., Lemna sp. vb.)

Gölet tasarımında göz önünde bulundurulan bir diğer önemli konu zonlama olmuştur. Göletin bir yandan rekreasyon faaliyetlerine hizmet ederken diğer yandan biyolojik çeşitliliği arttıracak unsurları barındırması öngörüldüğü için tasarım aşamasında farklı fonksiyonların ön planda tutulduğu bir zonlama yapılmıştır. Su içi, kıyı, bataklık ve su kenarı zonlarını tercih eden bitki ve hayvan türleri için uygun yaşama ortamları oluşturulmuştur. Göleti besleyen derenin bağlantı noktasından itibaren, suyun akışı farklı derinliklerde bölmelerle kontrol edilerek bu farklı zonların uygulaması gerçekleştirilmiştir. Su içi, su kenarı ve bataklık zonu bitkilerinin dikileceği bölmelerin zeminine, organik madde bakımından zengin materyal serilmiştir 
(Şekil 10). Rekreasyon faaliyetleri için kullanılacak olan geniş bölmeye organik madde ilavesi yapılmamış, doğal kil zemin muhafaza edilmiştir.

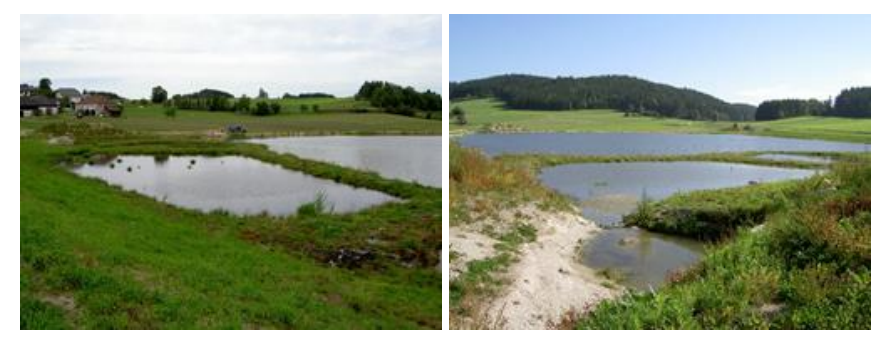

Şekil 10. Su içi, kıyı, bataklık ve su kenarı zonlarını tercih eden bitki ve hayvan türleri için uygun yaşama ortamları oluşturmak üzere tasarlanan alt mekanlar.

Gölde yüzmek ve sandalla gezmek gibi diğer rekreasyonel faaliyetlere tahsis edilmek üzere tasarlanan bölümde, kumdan küçük bir kıyı bandı oluşturulmuş ve yüzmek üzere güvenli olan bölge, yöreden temin edilen kayalarla sınırlandırılmıştır (Şekil $11)$.
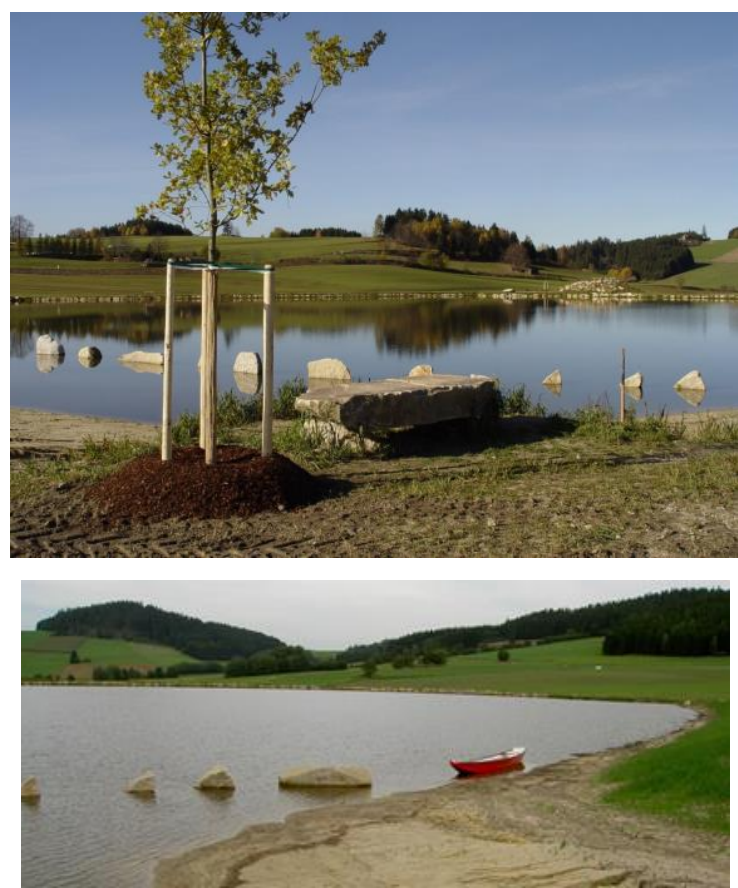

Şekil 11. Biyolojik göletin rekreasyonel faaliyetler için ayrılmış olan bölmesi ve küçük bir kumsalla ilişkilendirilmiştir.

Projeden önce atıl bir halde, borularla ve kanallarla Ottenschlag Köyü'nden tahliye edilen Grasbach Deresi projelendirme sürecinde göleti besleyen ana bileşen olarak restore edilmiş ve yer yer göletin bölmeleriyle ilişkilendirilen kısımlara borularla taşınarak, uygulama tamamlandıktan sonra, dolum noktaları habitatların içerisine kamufle edilmiştir (Şekil 12). Dere 350 mtül boyunca restore edilmiş ve göl ekosisteminin bir bileşeni haline getirilmiştir.
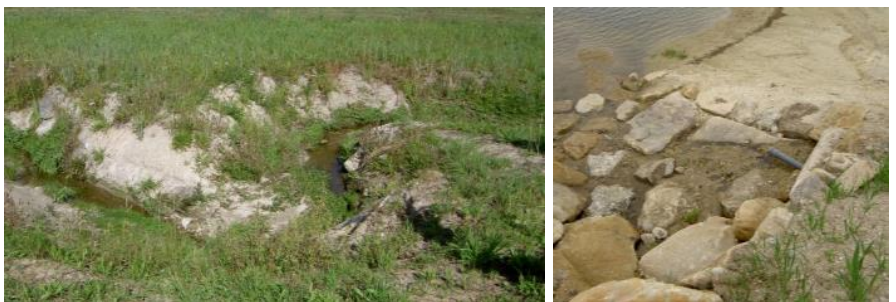

Şekil 12. Doğal akışına terk edilerek restore edilen Grasbach Deresi, biyolojik göleti beslemek üzere değerlendirilmiştir.

Bölgenin önemli sorunlarından olan su taşkınlarının önlenmesi, projenin birincil hedefleri arasında yer almıştır. Gölet, orta eğimli bir yamaçta yer alan köyün devamında, topoğrafyanın çanak şeklini aldığı düzlükte konumlandırılarak, fazla yağış sularını burada depolaması sağlanmıştır. Ekstrem yağışların kontrollü olarak deşarj edilmesini sağlamak üzere ise belli bölgelerde tahliye noktaları oluşturulmuştur (Şekil 13).

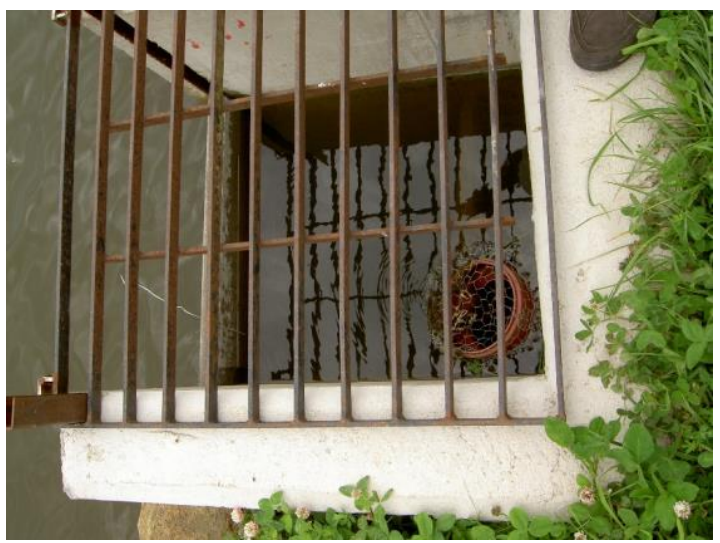

Şekil 13. Gölette suyun istenen düzeyden fazla yükselmesini engelleyen ve taşkınların oluşmasını önlemek üzere fazla suyun uzaklaştırıldığı deşarj noktası.

Sürdürülebilir kalkınma prensiplerinin benimsendiği projede, dikkat edilen bir diğer husus da imalatların mümkün olduğunca köy halkına öncelik verilerek yaptırılması olmuştur. Örneğin doğa gözlemi faaliyetleri için tasarlanan ahşap iskelenin üretimi, köy sakini olan marangoza yaptırılmıştır (Şekil 14). Keza işçilik, taş ustalı̆̆ı benzeri iş kalemleri için köy sakinlerinden destek alınmıştır. Bu yaklaşım ile proje için yapılan harcamaların köy ekonomisini desteklemesi sağlanmıştır.
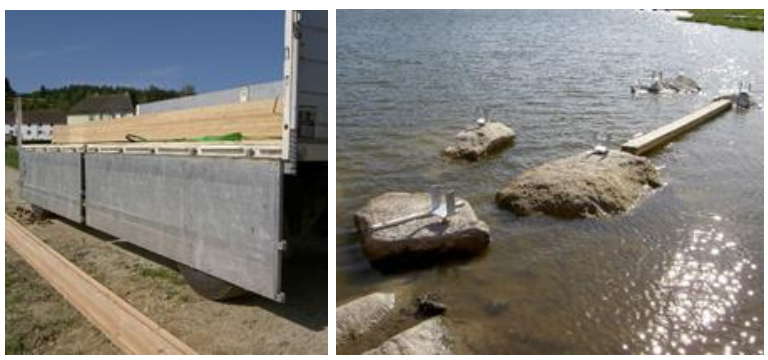

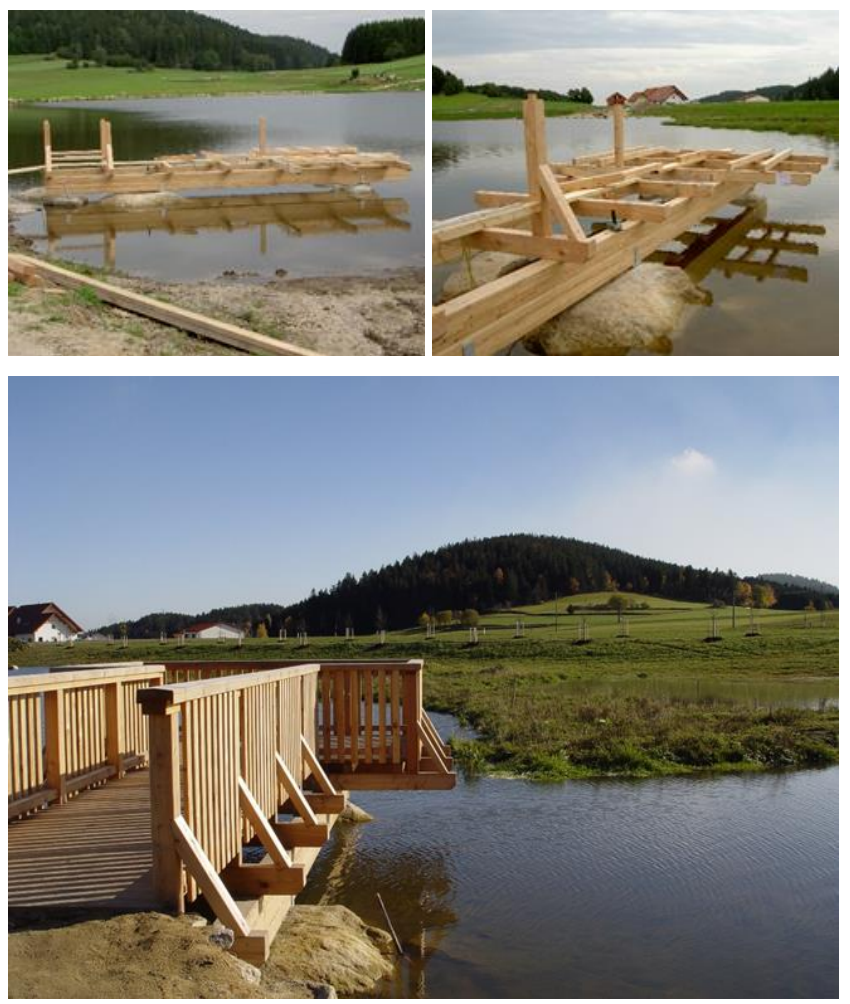

Şekil 14. Köy sakini olan marangoza yaptırılan iskele, doğa gözlemleri için uygun bir mekân teşkil etmektedir.

Başta kertenkele benzeri sürüngenler ve küçük memeliler için yaşam ortamı teşkil etmesi için tasarlanan ve büyük blok taşların istiflenmesiyle oluşturulan tepeciklere yine doğal taşlardan basamaklar eklenerek aynı zamanda ziyaretçiler için manzara seyir amacıyla kullanılması sağlanmıştır (Şekil 15). Bu sayede gölet için yapılan kazılarda açığa çıkan blok taşlar ve kayalar da projenin bir parçası olarak değerlendirilmiştir.
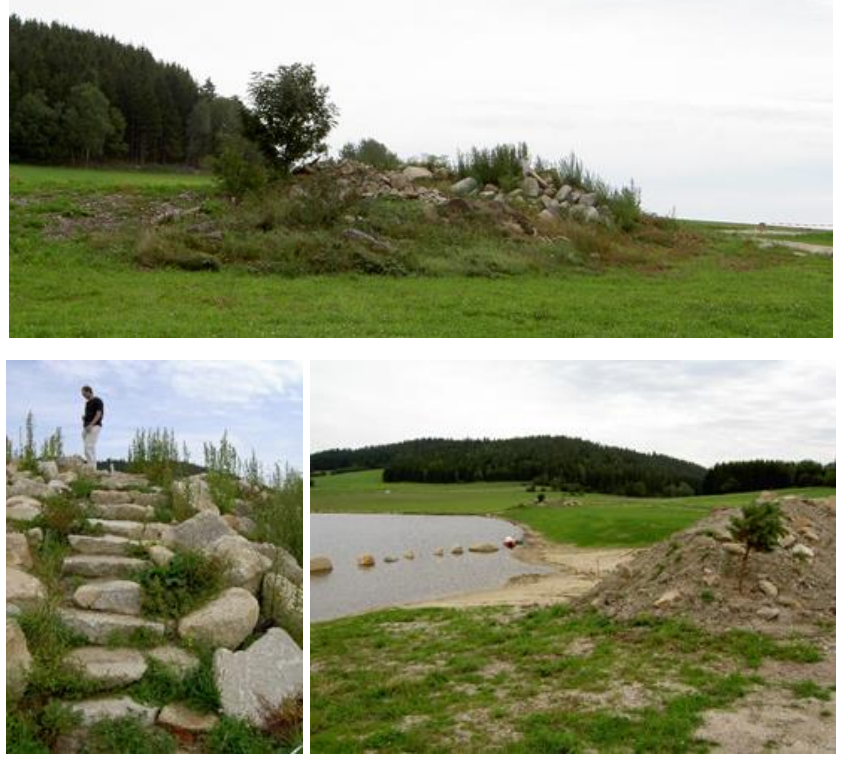

Şekil 15. Gölet kazısı sırasında açığa çıkan blok taşlar ve kayaların üst üste istiflenmesiyle oluşturulan ve göletin etrafında çeşitli yüksekliklerde olmak üzere altı noktada konumlandırılan

ve kara bitkileriyle bitkilendirilen tepecikler, bir yandan ziyaretçiler için manzara seyir amaçlı kullanılırken diğer yandan sürüngenler ve küçük memeliler için yaşama ortamı teşkil etmektedir.
Kültürel peyzajlar, geleneksel karakteristiklerle beslenen yapılar olduğu için sürdürülebilir kalkınmayı ve biyolojik çeşitliliği desteklemek üzere yapılan peyzaj uygulamalarında, kültürel yapıyı yansıtacak unsurlara yer verilmesi de önem kazanmaktadır. Bu nedenle göl kenarında oluşturulan yürüyüş yoluna gölge sağlaması için planlanan allede, yöresel meyve ağacı türleri tercih edilmiştir (Şekil 16-d). Bu tercih bir yandan ziyaretçilere yörenin karakteristik yapısını tanıtırken diğer yandan geleneksel dokunun yaşatılmasına da hizmet etmektedir.

Bir yıl içerisinde projelendirme ve uygulama süreci tamamlanan peyzaj projesi, köy kalkınması ve sürdürülebilir planlama adına yöreye önemli bir katma değer sağlamıştır. Projelendirme ve uygulama süreci, 2007-2008 yılları arasında gerçekleştirilmiş ve \%100 oranında tamamlanmış olan projenin ayrıntılarına aşağıda yer verilmiştir:

Uygulayıc1 Firma: TBK - Büro für Ökologie und Landschaftsplanung (AT) (URL-2).

\section{Proje Ekibi:}

Univ.-Lektor Dipl.-Ing. Dr. Harald Kutzenberger (TBK adına ekoloji ve peyzaj planlamadan sorumlu uzman): Koordinasyon, tasarım, inşaat sırasında saha gözetimi, kontrol.

Peyzaj Yük. Mimarı Gül Aslı Aksu: Tasarım ve CAD, inşaat sirasında gözetim, kontrol.

Dr. Gabriele Kutzenberger: Tasarım, çevre eğitimi. Wolfgang Marthe: CAD, inşaat sırasında gözetim.

\section{Tartışma ve Sonuç}

Günümüzde ekosistem bozulmaları; yerel, bölgesel, ulusal ve hatta küresel ölçekte etkilerini göstermektedir. Su rejimi bozulmakta, kaynaklar tükenmekte, hava-toprak-su kirliliği ve buna bağlı sağlık problemleri artmakta, biyolojik çeşitlilik azalmakta, türler ve habitatlar tükenmektedir. Tüm insanlığg ilgilendiren bu problemin aşılması ve dünya doğal-kültürel kaynaklarının sürdürülebilirliğnin sağlanması için özellikle mekânsal planlama ve tasarımla uğraşan disiplinlere önemli sorumluluklar düşmektedir. Küresel boyuta varabilen yansımaları nedeniyle çevrenin sürdürülebilir planlaması ve yönetimi konuları Birleşmiş Milletler, Avrupa Birliği gibi uluslararası organizasyonların da ana gündem maddesi haline gelmiştir. Konuyla ilgili imzalanan ve ülkemizin de taraf olduğu çok sayıda sözleşme (APS, Biyolojik Çeşitlilik, İklim Değişikliği vb.) ülkelere ayrıca yasal anlamda da önemli sorumluluklar yüklemektedir.

Kültürel peyzajlar, doğal-kültürel karakteristikler gereği sürdürülebilir planlamaya yön verecek önemli ipuçları barındırmaktadır. Bu nedenle gerek peyzaj planlama ve yönetimi gerekse tasarım süreçlerini başarıyla yönetmek üzere ele alınması gereken yapılardır.

Kültürel peyzajlar, ekosistem fonksiyonları ile kullanıcı arasında köprü görevi görmektedir. $\mathrm{Bu}$ nedenle kültürel peyzajların sürdürülebilirlik ilkeleri çerçevesinde planlanması ve düzenlenmesi; yerel, bölgesel, ulusal ve hatta uluslararası ölçekte ekosistemlerin korunması, biyolojik çeşitliliğin arttırılması ve kullanıcı ihtiyaçlarının gözetilmesi anlamında önemli bir adım taşı teşkil etmektedir.

“Avrupa Peyzaj Sözleşmesi”, "Yeşil Mutabakat” gibi habitatların korunmasını, geliştirilmesini ve sürdürülebilir kullanımlarının sağlanmasını hedefleyen ve düzenleyen 
uluslararası çerçeveler, peyzaj planlama disiplinine önemli sorumluluklar yüklemektedir. Sürdürülebilir peyzaj planlama ve yönetimi süreci çok bileşenli kompleks bir yapının bütüncül bir bakış açısıyla ele alınmasını gerektirmektedir. Bu anlamda doğal ve kültürel karakteristiklerin iyi değerlendirilmesi ve bileşenler arası ilişkilerin anlaşılması önem kazanmaktadır.

“Ottenschlag Köyü Kırsal Kalkınma ve Mooswiesen Biyolojik Göleti Projesi”, tüm bu bileşenlerin bir bütün olarak değerlendirildiği ve koruma-kullanma dengesinin gözetildiği, sürdürülebilir çözüm önerilerinin getirildiği bir örnek olduğu için makaleye konu edilmiştir (Şekil 16).



Şekil 16. Ottenschlag Köyü ve Mooswiesen Biyolojik Göleti Peyzaj Projesi. Kaynak: URL-1

Projenin tasarım ve uygulama süreçlerinde sürdürülebilirlik kriterleri doğrultusunda öncelik verilen konular aşağıdaki gibi özetlenebilir:

- Projenin gelişim sürecinin her aşamasında paydaş katılımı sağlanarak, kullanıcı ihtiyaçları gözetilmiştir.

- Projenin tüm aşamalarında yöre halkına istihdam sağlanması için firsatlar sunulmuştur.

- Doğal potansiyeller firsata çevrilirken, yapılan düzenlemelerle koruma-kullanma dengesi kurulmuştur.

- Gölet tasarımında ekolojik döngülerin desteklenmesi ve biyolojik çeşitliliğin geliştirilmesi hedeflenmiştir. Hem taşkın ve sel felaketlerinin önüne geçebilecek nitelikte bir deşarj sistemi hem de yağış sularının hasadını sağlayan bir rezervuar alanı oluşturulmuştur.

- Biyolojik göletin zonlara ayrılarak farklı yoğunluklarda bitkilendirilmesi ve su seviyesinin kademeli tutulmasıyla, çeşitli habitatlar oluşturulmuş ve böylelikle biyolojik çeşitlilik arttırılmıştır.

- $\quad \mathrm{Su}$ ekosistemi dışında uygun yerlerde bitkilerin besin kaynağı ve barınma ortamı teşkil etme özelliklerine öncelik verilerek, kaya bahçesi, meyve ağacı allesi, otsu ve odunsu karasal habitatlar kurgulanmıştır.

- Kırsal kalkınma projesi bir yandan doğa gözlemi, yüzme, sandalla gezme, manzara seyir, doğa yürüyüşü, dalından meyve toplama vb. rekreasyonel faaliyetlere imkan tanırken diğer yandan ziyaretçi çeken faaliyetlerin arttırılmasıyla köye ekonomik girdi sağlayabilmiştir.

- Yapısal tasarımda hem yörenin karakteristik yapısını yansıtmak hem maliyeti düşürmek hem de bütünlük sağlamak açısından yörede doğal olarak bulunan granit tercih edilmiş yapı cepheleriyle uyum sağlayacak şekilde yol-kaldırım döşemesi, köprü malzemesi olarak kullanılmıştır.

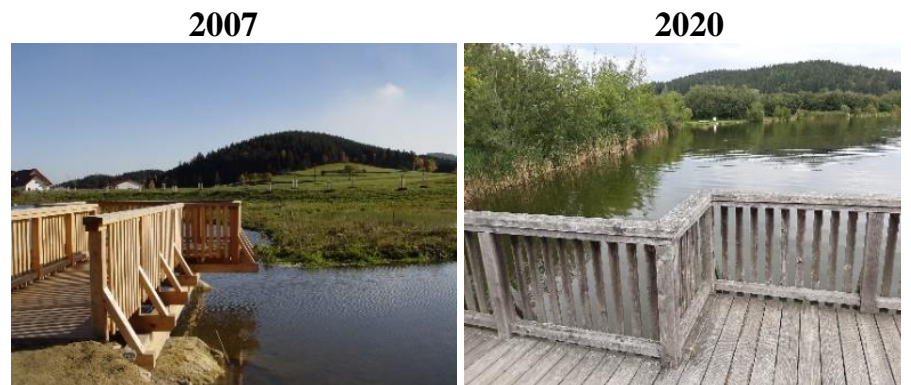

(a) Gölet üzerinde konumlandırılan ahşap iskele.

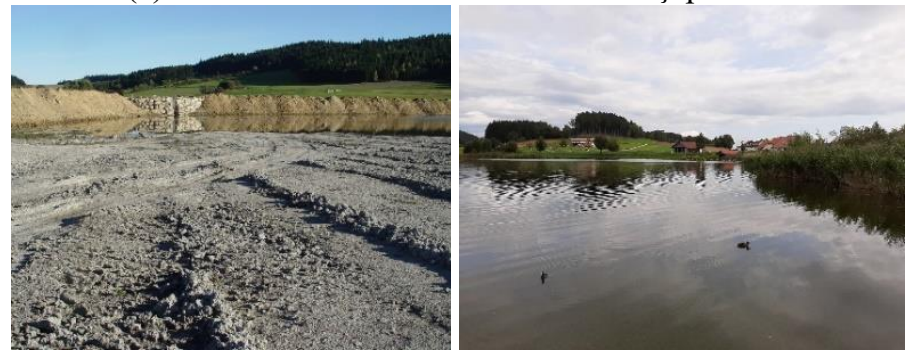

(b) Rekreasyonel kullanımlara olanak veren geniş gölet yüzeyi.
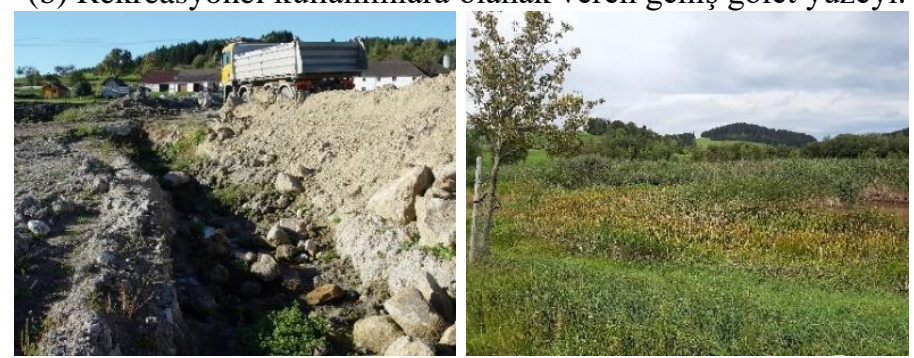

(c) Biyolojik çeşitliliği arttırmak üzere tesis edilen bataklık zonu.

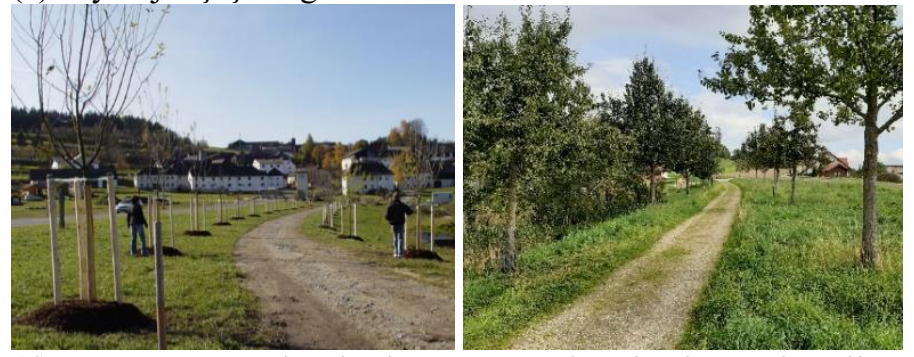

(d) Yöreye özgü geleneksel meyve ağaçlarıyla olușturulan alle.
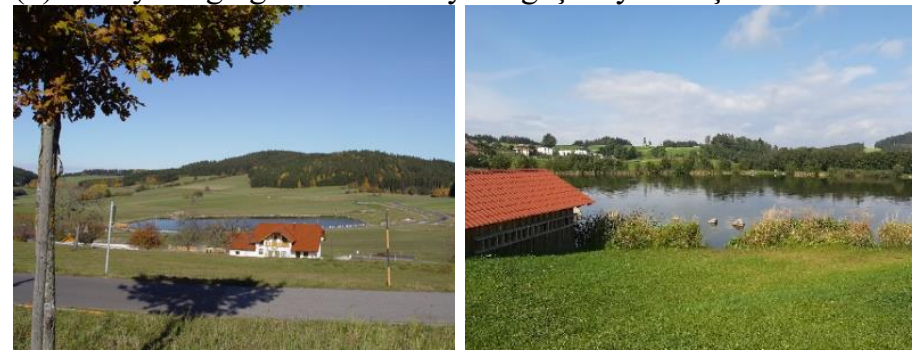

(e) Genel görünüm

Şekil 17. 2008 yılında uygulaması tamamlanan projenin 2020 yılındaki haliyle karşılaştırma yapıldığında, oluşturulan ekosistemlerin işlevselliğini sürdürdüğü görülmektedir.

Şekil 17'de projenin uygulandığ1 2007 yılındaki durumu, 2020 yılındaki haliyle karşılaştırmalı olarak verilmiştir. Yapılan bu karşılaştırma, sürdürülebilir kalkınma kriterleri benimsenerek uygulanan projenin, aradan geçen 13 yıla rağmen gerek ekosistem devamlılığı ve biyotop oluşturma kriterleri, gerek su yönetimi gerekse rekreasyon potansiyeli bakımından işlevselliğini sürdürebildiğini göstermektedir. 


\section{Teşekkür}

Gerçekleştirdiği çok sayıda sürdürülebilir kalkınma, peyzaj onarımı ve restorasyonu, peyzaj planlama ve yönetimi projesiyle peyzaj planlama mesleğine önemli katkılar sağlayan ve arşivini açmak suretiyle bu yayının hazırlanmasına destek olan başta Dipl.-Ing. Dr. Harald Kutzenberger'e ve tüm TBK Ofis (URL-2) çalışanlarına teşekkürü borç bilirim.

\section{Kaynakça}

Aksu, G.A., (2017). İstanbul-Beşiktaş İlçesi Ekolojik Planlama Yaklaşımlı Kentsel Peyzaj Planı ve Uygulama Stratejisi. TUBITAK-ARDEB 3501 kariyer Geliştirme Programı, proje No: 114-O-341, Proje Sonuç Raporu, 5.Bölüm (Tartışma ve Sonuç).

Aksu G.A., (2020). "Kentsel Peyzaj Planlama Yaklaşımları ve Peyzaj Kimliği." Kitap: Kentsel Peyzaj Planlama ve Sürdürülebilirlik. Ed.: Aksu, G.A. ve Suri, L., Cinius Yayınları. ISBN 978-625-7113-49-6

Antrop, M., (2006). "Sustainable Landscapes: Contradiction, Fiction or Utopia?" Landscape and Urban Planning, 75, S: 187-197.

Avrupa Peyzaj Sözleşmesi (APS), (2003). Avrupa Peyzaj Sözleşmesinin Onaylanmasının Uygun Bulunduğuna Dair Kanun. Türkiye Büyük Millet Meclisi Kanun No. 4881 Kabul Tarihi: 10.6.2003

$\begin{array}{cccc}\text { Avrupa Çevre } & \text { Ajansı, } & \text { (2021). } \\ \text { https://www.eea.europa.eu/soer/2015/europe/natural-capital- }\end{array}$ and-ecosystem-services\#note3 Son erişim tarihi: 26.02.2021

Avrupa Komisyonu, (1995). Recommendation on the integrated conservation of cultural landscape areas as part of landscape policies (Peyzaj Politikalarının Bir Parçası Olarak Kültürel Peyzaj Alanlarının Bütünleşmiş Korunması Tavsiye Kararı) (95/9)https://www.icomos.org/centre_documentation/coe_en g.htm

https://rm.coe.int/CoERMPublicCommonSearchServices/Di splayDCTMContent?documentId=09000016804fd025

Avrupa Komisyonu, The European Green Deal, (2021). https://ec.europa.eu/info/strategy/priorities-2019-

2024/european-green-deal_en Son erişim tarihi: 26.02.2021

Avrupa Yeşil Mutabakatı Türkçe Çevirisi. http://yesildusunce.org/dl/uploads/yesilavrupamutabakati.pd f Son erişim tarihi: 26.02 .2021

Bailey, R.G., (2002). Ecoregion-Based Design for Sustainability. Springer-Verlag New York, ISBN 0-387-95430-9

Bastian, O., Grunewald, K., Syrbe, U., (2013). "Klassifikation von ÖSD.” Kitap: Ökosystemdienstleistungen, Ed.: Grunewald, K. ve Bastian, O., Springer Verlag Berlin Heidelberg. S.:48-56.

Birkhofer, K., Diehl, E., Andersson, J., Ekroos, J., Früh-Müller, A., Machnikowski, F., Mader V.L., Nilsson, L., Sasaki, K., Rundlöf, M., Wolters V., Smith, H.G., (2015). "Ecosystem services-current challenges and opportunities for ecological research." Frontiers in Ecology and Evolution 2, Article 87: 1-10.
Christensen N.L. ve Franklin J.F., (1997). "Ecosystem Function and Ecosystem Management.” Kitap: Ecosystem Function \& Human Activities. Ed.: Simpson R.D. ve Christensen N.L., Springer, Boston, MA.

COM - Commission of the European Communities, (2011). Our life insurance, our natural capital: an EU biodiversity strategy to 2020. Communication from the commission to the European parliament, the council, the economic and social committee and the committee of the regions. Brussels, 3.5.2011; COM (2011) 244 final. http://eurlex.europa.eu/legalcontent/EN/TXT/PDF/?uri=CELEX:52011DC0244\&from= de

COM - Commission of the European Communities, (2013). Guidelines on Climate Change and Natura 2000. Dealing with the impact of climate change. On the management of the Natura 2000 Network of areas of high biodiversity value. Technical Report - 2013068. http://ec.europa.eu/environment/nature/climatechange/pdf/G uidance\%20document.pdf

Darmstad, W.E., Olson, J.D., Forman, R.T.T., (1996). Landscape ecology principles in landscape architecture an land-use planning. USA: Harward University Graduate School of Design, Island Press, American Society of Landscape Architects. ISBN 1-55963-514-2.

Demuth, B., Heiland, S., Wiersbinski, N., Hildebrandt, C., (2014). Energielandschaften - Kulturlandschaften der Zukunft? Bundesamt für Naturschutz, BfN-Skripten 364, Almanya.

Dicks, L., (2008). Giriş ve Ilıman Ormanlar. Kitap: Dünya Önemlidir. Bir Ekoloji Ansiklopedisi. Ed: DeRotschild, D., Türkçe Yayın Yönetmeni: Çam, İ.A., Çeviri: Türer, L., Dorling Kindersley Limited, Londra, Tudem, İzmir. ISBN: 978-9944-69-311-0.

Forman, R.T.T., (2008). Urban Regions. Ecology and Planning Beyond the City. Cambridge University Press, UK., ISBN13: 978-0-521-67076-0 (PB).

Haines-Young, R. ve Potschin, M., (2013). Common International Classification of Ecosystem Services (CICES): Consultation on Version 4, August-December 2012. EEA Framework Contract No: EEA/IEA

Hampicke, U., (2018). Kulturlandschaft - Äcker, Wiesen, Wälder und ihre Produkte. (Kültürel Peyzaj - Tarım Alanları, Çayırlar, Ormanlar ve Ürünleri), Springer Verlag, Almanya. ISBN 978-3-662-57752-3

Hartz, A. ve Brenner J., (2017). Regionale Landschaftsgestaltung - ein Modellvorhaben des Bundes. Ländlicher Raum, Kulturlandschaften, 01/17, S: 32-35, Agrarsoziale Gesellschaft e.V.

Heiland, S., Mengel, A., Hänel, K., Geiger, B., Arndt, P., Reppin, N., Werle, V., Hokema, D., Hehn, C., Mertelmeyer, L., Burghardt, R., Opitz, S., (2017). Bundeskonzept Grüne Infrastruktur Fachgutachten. Bundesamt für Naturschutz, BfN-Skripten 457, Almanya.

Kasemir, B., Jaeger, C.C., Jäger, J., (2003). "Citizen Participation in Sustainability Assessments." Kitap: Public Participation in Sustainability Science A Handbook. Ed.: 1071 
Kasemir, B., Jäger, J., Jaeger, C.C., Gardner, M.T., Cambridge University Press, UK, ISBN - 13: 978-0-51106976-5 eBook (EBL).

Kayacan, T., Özel, Y., Kayacan, B. (2019). Kente Kazandırılan Yeni Yaşam Alanları. Avrupa Bilim ve Teknoloji Dergisi, Say1 16, S. 679-687. DOI: 10.31590/ejosat.592411.

Kayın, E., (2012). Bir "Kültürel Manzara-Kültürel Peyzaj" Öğesi Olarak Kırsal Yerleşimlerin Korunmasına Yönelik Kavramsal ve Yasal İrdelemeler. Mimarlık Dergisi Sayı: 367, Eylül-Ekim, 2012. http://www.mimarlikdergisi.com/index.cfm?sayfa=mimarlik \&DergiSayi $=381 \&$ RecID $=2998$

Lennon, J., (2015). Cultural Landscape Management Practice: Some Australian Case Studies. Kitap: Conserving Cultural Landscapes Challenges and New Directions. Part IV: Confronting the Everyday Challenge of Cultural Landscape Management Ed.: Ken Taylor, Archer St Clair ve Nora J. Mitchell, Routledge

MA-Millennium Ecosystem Assessment, (2005). Ecosystems and Human Well-being: Synthesis. Island Press, Washington, DC. 137 S.

McHarg, I.L., (1992). Design With Nature. John Wiley \& Sons, Inc., ISBN: 0-471-55797-8.

Miller, W., Collins, M.G., Steiner, F.R., Cook, E., (1998). “An Approach for Greenway Suitability Analysis." Landscape and Urban Planning, 42, S: 91-105.

Naveh, Z., (2001). "Ten major premises for a holistic conception of multifunctional landscapes." Landscape and Urban Planning, 57, S:269-284.

Potschin, M. ve Haines-Young, R., (2006). "Rio+10, Sustainability Science and Landscape Ecology." Landscape and Urban Planning, 75, S: 162-174.

Saunders, M.E. ve Luck, G.W., (2016). "Limitations of the ecosystem services versus disservices dichotomy." Conservation Biology 30(6): 1363-1365.

Schrapp, L., Garschhammer, J., Meyer, C., Blum, P., Reinke, M., Mewes, M., (2020). Ökosystemleistungen in der Landschaftsplanung. Abschlussbericht zum gleichnamigen
F+E-Vorhaben (FKZ 351582 3000), BfN-Skripten 568, Almanya.

Sundseth, K. ve Creed, P., (2008). NATURA 2000, Protecting Europe's Biodiversity. European Commission, Directorate General for the Environment (Avrupa Komisyonu, Çevre Genel Müdürlüğü), Birleşik Krallık. ISBN 978927908308 2

Suri, L., (2018). "Search for Plans for Drinking Water Basins: Ömerli Drinking Water Basin as an Example," Journal of Multidisciplinary Research (1947-2900), 1(1), 0-0

T.C. Dışişleri Bakanlığı. Sürdürülebilir Kalkınma. http://www.mfa.gov.tr/surdurulebilir-

kalkinma.tr.mfa\#: :text=3\%2D14\%20Haziran\%201992\%20 tarihleri,a\%C3\% A7\%C4\%B1s\%C4\%B1ndan\%20\%C3\%B6 nemli\%20bir\%20ad\%C4\%B1m\%20olmu\%C5\%9Ftur. Son erişim tarihi: 26.02 .2021

TEEB - The Economics of Ecosystems and Biodiversity, (2010). TEEB Ecological and Economic Foundations. Earthscan, Londra.

Tülek, B. ve Saner, H. S., (2020). Kaderine Terk Edilmiş Bir Köy Olarak Lübbey Köyü Peyzaj Özelliklerinin İncelenmesi. Avrupa Bilim ve Teknoloji Dergisi, (18), 10261037.

UN, WCED (the World Commission on Environment and Development), 1987. Brundtland Report. Our Common Future.

URL-1 UNESCO, Dünya Kültürel ve Doğal Mirasının Korunmasına Dair Sözleşme. 14.02.1983 tarih ve 17959 sayılı Resmî Gazete. https://teftis.ktb.gov.tr/TR263665/dunya-kulturel-ve-dogal-mirasin-korunmasisozlesmesi.html Son erişim tarihi: 12.11.2021

URL-2 TBK - Büro für Ökologie und Landschaftsplanung. http://www.tb-kutzenberger.com/index.php?lang=en Son erişim tarihi: 26.07 .2021

Ürün, Ş., (2016). Dünya Kültürel ve Doğal Mirasın Korunmasına Dair Sözleşme: Doğal Miras Alanları Başvuru, Adaylık ve Değerlendirme Süreçleri. Tez. UNESCO Türkiye Millî Komisyonu. 